
Outsourcing On Sustainable Supply Chain And Business Performance, BMIJ, (2018), 6(4): 1379-1394 doi: http://dx.doi.org/10.15295/bmij.v6i4.287

\title{
AN EXAMINATION ON THE IMPACT OF OUTSOURCING ON SUSTAINABLE SUPPLY CHAIN AND BUSINESS PERFORMANCE
}

\author{
Vural ÇAĞLIYAN ${ }^{1}$ \\ Emel GELMEZ ${ }^{2}$ \\ Minenur Sezer DİLEK ${ }^{3}$
}

Received Date (Başvuru Tarihi): 12/09/2018

\author{
Accepted Date (Kabul Tarihi): 19/12/2018 \\ Published Date (Yayın Tarihi): 04/01/2019
}

\begin{abstract}
As a requirement of competitiveness, businesses procure those goods and services which are beyond their own fields of activity from specialized businesses. Based on this requirement, examination of the effect of outsourcing, one of the crucial instruments for businesses in gaining competitive advantage, on sustainable supply chain performance and business performance, is of importance in terms of bringing a point of view on the dimensions of the ongoing competition in sectoral sense and enabling the businesses to assess their own structures. In this context, the effect of outsourcing by businesses operating in food industry in the province of Konya on sustainable supply chain performance and business performance was examined in this study. Structural equation modeling was utilized to analyze the correlation between the variables. While no statistically significant correlation could be determined between outsourcing and sustainable supply chain perforrmance, it was found out that a statistically significant correlation existed between sustainable supply chain performance and business performance as well as between the outsourcing and business performance.

Keywords: Outsourcing; Sustainable Supply Chain Performance; Business Performance; Structural Equation Modeling
\end{abstract}

JEL Kodlart: M11, M19, L25

\section{DIŞ KAYNAK KULLANIMININ SÜRDÜRÜLEBILIIR TEDARIKK ZINCİRI VE ISSLETME PERFORMANSINA ETKISII ÜZERINE BİR İNCELEME}

\section{$\ddot{O} Z$}

Rekabetçiliğin bir gereği olarak işletmeler kendi faaliyet alanlarl dışındaki mal ve hizmetleri kendi alanlarında uzman işletmelerden sağlamaktadırlar. Bu gereklilikten hareketle işletmeler açısından rekabetçi üstünlük elde edilmesinde önemli araçlardan birisi olan dış kaynak kullanımının sürdürülebilir tedarik zinciri performansı ve işletme performansı üzerindeki etkisinin incelenmesi sektörel anlamda süren rekabetin boyutlarına bir bakış açısı kazandırması ve işletmelerin kendi yapılarını değerlendirebilmeleri açısından önem arz etmektedir. Bu bağlamda bu çalışmada Konya ilinde gıda sektöründe faaliyet gösteren işletmelerin dış kaynak kullanımının sürdürülebilir tedarik zinciri performansl ve işletme performansı üzerindeki etkisi incelenmiştir. Değişkenler arasındaki iliş̧iyi irdelemek amacıyla yapısal eşitlik modelinden yararlanılmıştır. Yapılan analiz sonucunda dış kaynak kullanımı ile sürdürülebilir tedarik zinciri performansı arasında istatistiksel bakımdan anlamlı bir ilişki tespit edilememiş olmakla birlikte sürdürülebilir tedarik zinciri performansı ve işletme performansı ve ayrıca dış kaynak kullanımı ile işletme performansı arasında istatistiksel bakımdan anlamlı bir ilişki olduğu tespit edilmiştir.

Anahtar Kelimeler: Dış Kaynak Kullanımı; Sürdürülebilir Tedarik Zinciri Performansı; Işsletme Performansı; Yapısal Eşitlik Modeli

JEL Kodlart: M11, M19, L25

\footnotetext{
${ }^{1}$ Assoc. Prof., Selcuk University, vcagliyan@selcuk.edu.tr

${ }^{2}$ Dr., Selcuk University, emelgelmez@ selcuk.edu.tr

${ }^{3}$ Selcuk University, Institute of Social Sciences, minesezerdilek89@gmail.com
}

https://orcid.org/0000-0002-7964-8840 https://orcid.org/0000-0002-8774-607X https://orcid.org/0000-0001-6502-882X 


\section{INTRODUCTION}

In the last thirty years, as a result of the changes in the structure of competition that have occurred both in quantity and quality, the enterprises are now willing to get many products which are not their main field of expertise from other suppliers. In other words, enterprises are outsourcing more and more recently because of getting advance in their products of expertise. In the beginning, products and services obtained via outsourcing were limited to cleaning, food, and security which cannot have direct impact on enterprises' competitiveness. However, over the time, there has been a change in the products and services provided from external sources.

Carrier industries such as automotive are seen to benefit from outsourcing in virtually all kinds of activities, except assembly operations which is the main activity of the industry. Applications such as the transfer of all activities to suppliers including the design of any part and/or system are the sign of a change. In this way, enterprises need to restructure their supply chains in a process where even product design is handed over to suppliers. At this point, the structure of the supply chain formed during the restructuring process must be sustainable at the same time.

This study examines the impact of outsourcing - which has a wide application area by enterprises- on supply chain and business performances. Each variable that is vital to the businesses and forms the basis of this study have a separate working area in the relevant literature. In this context, this study will contribute to the literature because of its design of combining the variables together and the limitation of studies set in this perspective.

\section{LITERATURE}

\subsection{Outsourcing}

In a dynamic competitive business environment, enterprises should not behave cumbersome in order to adapt to changing and competitive conditions. Today, strategies that bring the success to enterprises are depending on lean perspective and fast adaptation to changing conditions with this perspective. One of these strategies is to utilize outsourcing which aims increasing organizational downsizing and flexibility by transferring activities other than the core competencies of the company to the other enterprises (Güleş et al, 2012: 121). Outsourcing, which has been recognized as a field of research in many fields from the management of information systems to international affairs (Giustiniano and Clarioni, 2013: 
155), has been adopted as a useful management strategy between enterprises and has been widely used by many enterprises.

Outsourcing is defined as the process of providing a specific product or service to a business that called manufacturer, buyer, or customer from a business identified as a supplier or a service provider (Mieghem, 1999: 954- 955). At the same time, Outsourcing Institute defines outsourcing as "a performed activities traditionally dealt with by internal staff" (Sarifuzzaman, 2012: 4).

Lacity (1995: 88) notes that outsourcing is primarily a matter of outsourcing activities that are outside the organization's strategic activities, but require specialization. Outsourcing in this direction is monitoring the supply method for functions which is not core competency for allowing customer enterprise to focus more on their main capabilities (Momme, 2002).

Outsourcing allows businesses to focus their resources and energies on areas where they have profession and best for value creation (Fill and Visser, 2000: 45). Businesses are turning towards outsourcing to reduce or share risk (May, 1998: 139). Therefore, there are many reasons that lead an enterprise to outsourcing. Some of these can be listed as follows (Hila and Dumitraşcu, 2014: 331).

- To advance external suppliers' abilities,

- To use resources for other purposes of businesses,

- Reduction and control of operating costs,

- Infusion of cash by selling assets to provider,

- Decrease the risk,

- Lack of internal resources,

- The need to focus more on the core activities of the business,

- Scale economies,

- Benchmarking.

Overall, the most important reason for businesses choosing outsourcing is that small businesses have the resources and the capacity to provide competitive advantage while meeting priority and supportive activities. By developing a few basic competencies, an enterprise will increase their chance of providing a continuous competitive advantage. Addition to this, the activities that the enterprises should perform are provided via outsourcing will allow enterprise to concentrate fully on the core competencies of the business (Aydin, 
2016: 67). Outsourcing in this framework is not only seen as a means of reducing costs, but also emphasizes the transfer of intellectual capital (Giustiniano and Clarioni, 2013: 156).

\subsection{Sustainable Supply Chain and Business Performance}

Supply chain management has become one of the main tools of businesses day-to-day operations to control costs and improve economic performance (Hong et al., 2018: 3508). Supply chain management requires the efficient use of internal and external supplier capabilities and technology as well as to create best coordinated supply chain. In this way, it is ensured that intra-company competition is transferred to supply chain competition and finally to business performance (Mariadoss et al., 2016: 3406). At the same time, supply chain management facilitates integration between customer base, distribution network, in-house and supply-based activities. Supply chain management practices have a major impact on organizational performance, sustainability performance and how they are perceived by external stakeholders (Bastas and Liyanage, 2018: 727).

Sustainability which is considered as the main component of the competitive advantage (Zhang et.al., 2018: 206), has become a very important concept both in today's business world and in the broader segments of society (Carte ve Easton, 2011: 46). While Sustainable Supply Chain Management manages the flow of materials, information and capital through a supply chain and the business associations of companies on the chain, based on the sustainable development expectations of stakeholders and customers, it also presents objectives and achievement for three different dimensions (economic, environmental and social) of sustainable development (Seuring and Müller, 2008: 1700). While the discussion on sustainable supply chain management continues, there is a general agreement on some basic definitions. Sustainability is regarded as a normative concept as to how people should behave towards the natural environment and how they carry responsibility for each other and for future generations (Zhang et al., 2018: 207).

Sustainable Supply Chain Management is defined as a set of management practices that include the necessity of environmental impacts, to take into account all the stages in the value chain for each product, and a multidisciplinary flow that covers the entire product life cycle (Gupta, 2011: 235). Sustainable supply chain analysis allows identification of misunderstandings between budgeting resource and consumer choice (Gomez-Luciano et al., 2018: 312). 
In recent years, using the concept of sustainability in the context of supply chain management has gained great importance. Measuring, developing and forwarding the sustainability performance of an enterprise's supply chain has become essential for the identification of objectives and future action plans (Saeed and Kersten, 2017: 1). In this context, as in most business activities, sustainable supply chain management is used to achieve specific performance targets for businesses (Beske-Janssen et al., 2015: 665).

\section{METHODOLOGY}

This part of the study will provide information on the purpose, hypothesis, methodology and findings of the field survey conducted.

\subsection{Research Methodology and Sampling}

The main purpose of the study is to examine the outsourcing activities of enterprises on sustainable supply chain performance and business performance in the food industry. Survey method is used as data collection tool and the universe of the study is defined as food enterprises operating in Konya. There are 867 businesses registered in the Konya Chamber of Commerce under these features. Businesses need to be of a certain size to be able to have a supply chain structure and be able to apply for outsourcing. In this framework, enterprises with less than 10 employees are excluded from the scope of the research. According to the records of the Konya Chamber of Commerce, there are a total of 300 enterprises with this condition and these enterprises have been determined as the main mass of the research.

The study is carried out through a sample that will represent the main mass of the research because of reaching the whole mass can be timely and costly. In the determination of the sample size, the table of possible sample size from a certain mass prepared by Yazicioglu and Erdoğan (2004: 50) is taken as a reference. In this context, for a main mass of 500 enterprises, \pm 0.10 sampling error; $p=0.5$ (the observation rate of $X$ in the main mass) and $q$ $=0.5$ (the unobserved ratio of $\mathrm{X}$ in the host) the determined sample size is 81 . If the main mass is including 100 enterprises, the sample size becomes 49. During the data collection process (June-December 2016) 120 questionnaires were obtained and sample size obtained showed the representative power of the main mass. Sampling method was preferred in determining the participants included in the survey. Sampling method is a favourable method for this kind of studies because of its quick access to the database (Nakip, 2013:227).

The survey form used in the research consists of two parts. In the first part, there are questions aiming to determine the demographic characteristics of the participants. In the 
second part, information on sustainable supply chain performance, outsourcing levels and business performance are included.

In order to measure sustainable supply chain performance of business, the scale developed by Zailani et al. (2012) was used. The scale consist of 14 questions and four dimensions. In the 5-point Likert type expressions, 1 represents "not at all", 5 represents "definitely like that".

In order to measure the outsourcing levels of the enterprises, a scale compiled from the activities evaluated by the outsourced enterprises in various studies (Karahan 2009 and Öz 2011) was utilized. A total of 17 areas of activity were used for outsourcing in the scale. Scale is a 5-point Likert-type and meaning 1 is "never used" and 5 is "used at a very high level".

In order to measure the business performance, the scale (consisting 6 questions and two dimensions) used by Alpay et al. (2008) and Erdirençelebi (2012) was utilized. The Scale is a 5-point Likert-type scale, meaning 1 is "I do not agree" and 5 is "strongly agree".

\subsection{Research Hypotheses}

A conceptual model has been developed in accordance with the purpose of the study and hypotheses are given on this model. The conceptual model and hypotheses of the research are shown in Fig. 1.

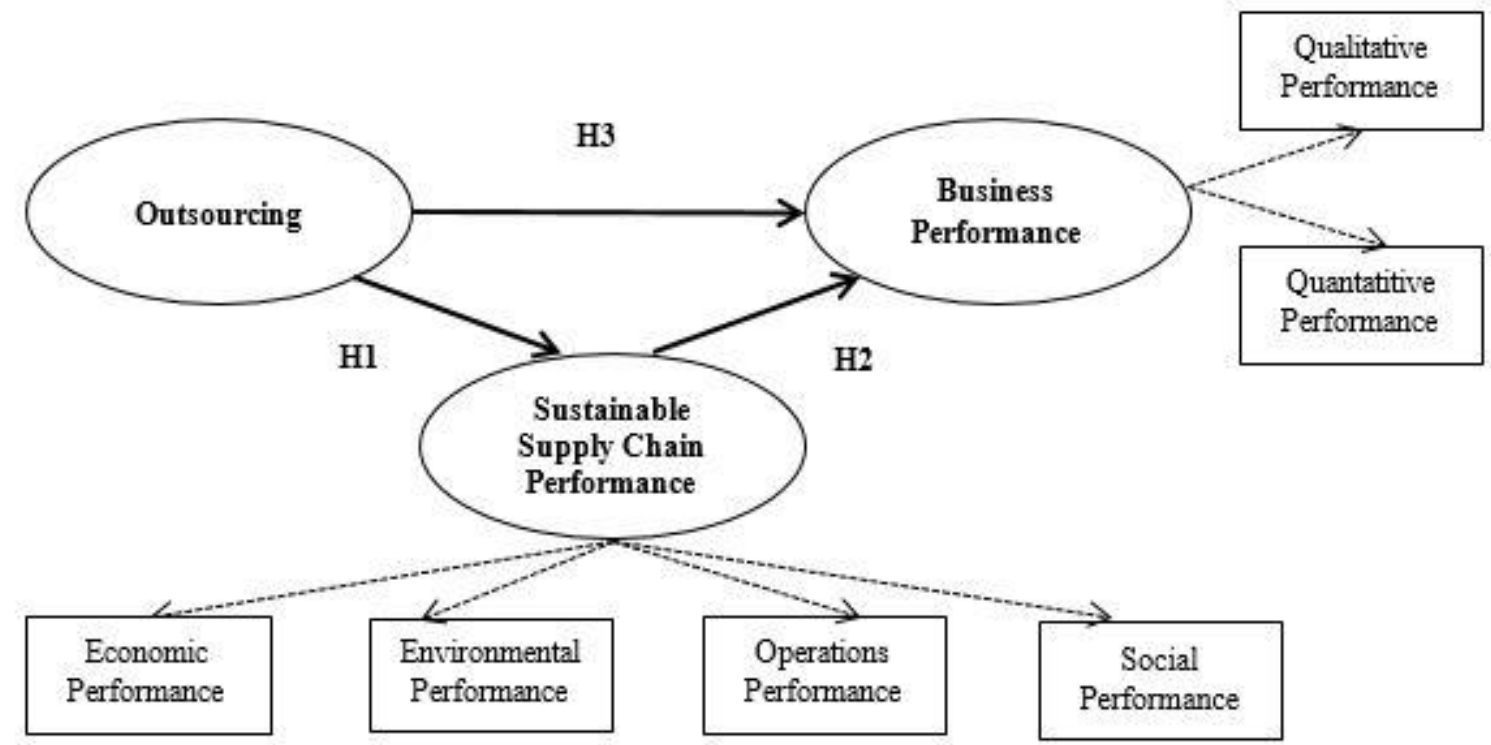

Figure 1. The Conceptual Model and Hypotheses of the Research 
The research hypotheses illustrated in Figure 1 are as follows:

Hypothesis 1: There is a relationship between outsourcing and sustainable supply chain performance.

Hypothesis 2: There is a relationship between sustainable supply chain performance and business performance.

Hypothesis 3: There is a relationship between outsourcing and business performance.

\section{FINDINGS}

\subsection{Information about Sample Enterprises}

According to enterprises details, 50.8\% (total of 61) of the enterprises operate international, 33.3\% (total of 40) are regional and 15.8\% (total of 19) operate nationally. When looking at the operating life of the enterprises, $29,3 \%$ of them are running over 31 years, $17,2 \%$ of them are running between $11-15$ years, $13,8 \%$ of them are running between 6-10 years and 13,8\% of them are running between 26-30 years, 10,3\% are running between 21-25 years, 7,8\% are running between $16-20$ years and 7,8\% are running between 1-5 years.

\subsection{Analysis of Data}

Structural Equation Modelling (SEM) was used to test the conceptual model of the research. SEM is a common testing method for models that can identify the causal relationship between variables and allows the theoretical models to be tested as a whole (Ayyıldız et al., 2006). The program of SPSS-Amos 18.0 was used to perform SEM analysis. Before the SEM analysis, the Exploratory Factor Analysis-EFA was carried out to investigate whether the scales' factor loads carry the dimensions stated in the literature. For this, SPSS-22 statistical package program was used.

\subsubsection{Exploratory Factor Analysis}

In the analysis of the research model, reliability analysis and exploratory factor analysis (EFA) were performed first.

Before examining the research model by structural analysis, by EFA, the dimensionality of the variables was investigated and the internal consistency (reliability) of the dimensions was examined. In Table 2, the Cronbach Alpha $(\alpha)$ values for each dimension on the scales and the variance explained (VE) in each dimension are indicated in parentheses. In addition, factor loads and other values for each statement of dimensions are also shown. For the calculation of factor loads for all scales in EFA, the Varimax Rotation Technique was 
applied, and the conditions of the Eigen Values of the factors to be greater than 1 and factor loads greater than 0.50 are sought in the results. For reliability analysis, Cronbach Alpha values should be equal to or greater than 0.70 . Prior to EFA, the total correlations of the items were assessed to improve the reliability of the scales, and the Bartlett Chi-Square Test for Sphericity values were calculated to test the appropriateness of the sample size to the factor analysis and the fit of KMO (Kaiser-Meyer-Olkin) values and the data to the factor analysis. The conditions of KMO value is greater than 0.60 and Chi-Square value is significant are sought. 
Table 2. Results of Exploratory Factor Analysis

\begin{tabular}{|c|c|c|c|c|c|}
\hline Scale & Dimensions & Items & Factor 1 & Factor 2 & Factor 3 \\
\hline \multirow{14}{*}{ 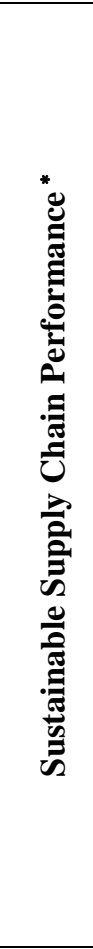 } & \multirow{5}{*}{ Operations } & $\begin{array}{l}\text { Ability to fulfil perfect order (complete, without any } \\
\text { delays and damage free) }\end{array}$ & 0,718 & & \\
\hline & & $\begin{array}{l}\text { Ability to quickly respond to changes to competitors } \\
\text { product offerings }\end{array}$ & 0,737 & & \\
\hline & & $\begin{array}{l}\text { Numbers of days for a supply chain to respond to } \\
\text { plan, source, make and deliver unexpected demand } \\
\text { variations. }\end{array}$ & 0,814 & & \\
\hline & & Ability to reduce manufacturing operating cost & 0,798 & & \\
\hline & & $\begin{array}{l}\text { Inventory days of supply/inventory turnover rate } \\
\text { (Numbers of days cash is tied up in inventory) }\end{array}$ & 0,842 & & \\
\hline & \multirow{2}{*}{ Economic } & $\begin{array}{l}\text { Significant improvement in terms of resources } \\
\text { management efficiency }\end{array}$ & & 0,863 & \\
\hline & & $\begin{array}{l}\text { Significant improvement in terms of sales and } \\
\text { market share }\end{array}$ & & 0,907 & \\
\hline & \multirow[b]{2}{*}{ Social } & Significant improvement in product image & & & 0,858 \\
\hline & & $\begin{array}{l}\text { Significant improvement in its image in the eyes of } \\
\text { its customer }\end{array}$ & & & 0,843 \\
\hline & & Eigen Value & 4,282 & 1,358 & 1,069 \\
\hline & & Variance Explained & 35,986 & 19,613 & 18,940 \\
\hline & & Total Variance Explained & & & 75,540 \\
\hline & & Cronbach's Alpha & 0,876 & 0,800 & 0,758 \\
\hline & \multicolumn{5}{|c|}{$\begin{array}{l}\mathrm{N}=120 ; \mathrm{KMO}=0,813 ; \text { Bartlett Sph. Test Chi-Square }=486,057, \mathrm{p}<0,001 ; \text { Factor Loads } \geq 0,50 ; \text { Scale } \\
\alpha=0,857\end{array}$} \\
\hline \multirow{11}{*}{ 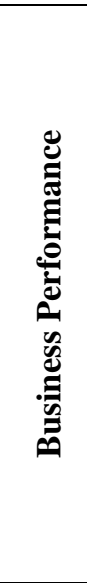 } & \multirow{3}{*}{$\begin{array}{l}\text { Qualitative } \\
\text { Performance }\end{array}$} & The quality of goods / service has increased. & 0,829 & & \\
\hline & & Skill of new product development has increased. & 0,841 & & \\
\hline & & $\begin{array}{l}\text { Internal / external customer satisfaction has } \\
\text { increased. }\end{array}$ & 0,808 & & \\
\hline & \multirow{3}{*}{$\begin{array}{l}\text { Quantitative } \\
\text { Performance }\end{array}$} & Sales have increased & & 0,858 & \\
\hline & & Market share has increased & & 0,886 & \\
\hline & & $\begin{array}{l}\text { The return of the investment was occurred as } \\
\text { planned. }\end{array}$ & & 0,704 & \\
\hline & & Eigen Value & 3,268 & 1,163 & \\
\hline & & Variance Explained & 38,313 & 35,530 & \\
\hline & & Total Variance Explained & & 73,843 & \\
\hline & & Cronbach's Alpha & 0,815 & 0,812 & \\
\hline & \multicolumn{5}{|c|}{$\begin{array}{c}\mathrm{N}=120 ; \mathrm{KMO}=0,782 ; \text { Bartlett Sph. Test Chi-Square }=239,540, \mathrm{p}<0,001 ; \text { Factor Loads } \geq 0,50 ; \text { Scale } \\
\alpha=0,831 .\end{array}$} \\
\hline \multirow{10}{*}{ 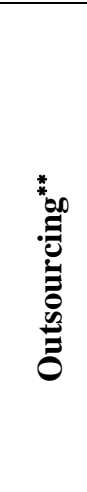 } & & Logistics & 0,685 & & \\
\hline & & Communication & 0,757 & & \\
\hline & & Staffing & 0,902 & & \\
\hline & & Training Activities & 0,724 & & \\
\hline & & Management Activities & 0,835 & & \\
\hline & & Administrative Activities & 0,829 & & \\
\hline & & Eigen Value & 3,766 & & \\
\hline & & Total Variance Explained & 62,767 & & \\
\hline & & Cronbach's Alpha & 0,879 & & \\
\hline & \multicolumn{5}{|c|}{$\mathrm{N}=120 ; \mathrm{KMO}=0,829 ;$ Bartlett Sph. Test Chi-Square=405,455, p<0,001; Factor Loads $\geq 0,50$} \\
\hline
\end{tabular}

\footnotetext{
* The Sustainable Supply Chain Performance scale consists of 14 items. As a result of the reliability analysis carried out, 3 items related to the environmental dimension and 1 item each related to the economic and social dimension were subtracted from the scale when the cronbach's alpha values were less than 0.70 and the total correlation values for each items were below 0,50.

** Outsourcing scale consists of 17 items. As a result of the reliability analysis, 11 items were subtracted from the scale because of the cronbach's alpha values were less than 0.70 and the item total correlation values were below 0,50.
} 


\subsubsection{Confirmatory Factor Analysis}

Confirmatory Factor Analysis (CFA) was used to validate the factors identified in EFA and to test the reliability and validity of the scale. CFA calculates some values showing the statistical significance and compatibility of the proposed model.

Table 3. Confirmatory Factor Analysis Results for Scales

\begin{tabular}{|c|c|c|c|c|c|}
\hline Scale & Dimensions & Items & $\begin{array}{l}\text { Standardized } \\
\text { Regression } \\
\text { Weight } \\
\end{array}$ & $\mathbf{t}$ & $p$ \\
\hline \multirow{9}{*}{ 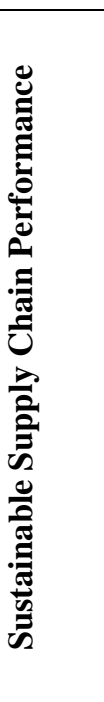 } & \multirow{5}{*}{$\begin{array}{l}\text { Operations } \\
\quad\left(\rho_{\mathrm{\eta}}=0,876\right. \\
\text { V.E }=0,588)\end{array}$} & $\begin{array}{l}\text { Ability to fulfil perfect order (complete, without any } \\
\text { delays and damage free) }\end{array}$ & 0,719 & 8,223 & $<0,001$ \\
\hline & & $\begin{array}{l}\text { Ability to quickly respond to changes to competitors } \\
\text { product offerings }\end{array}$ & 0,711 & 8,115 & $<0,001$ \\
\hline & & $\begin{array}{l}\text { Numbers of days for a supply chain to respond to } \\
\text { plan, source, make and deliver unexpected demand } \\
\text { variations. }\end{array}$ & 0,771 & 8,955 & $<0,001$ \\
\hline & & Ability to reduce manufacturing operating cost & 0,82 & 9,641 & $<0,001$ \\
\hline & & $\begin{array}{l}\text { Inventory days of supply/inventory turnover rate } \\
\text { (Numbers of days cash is tied up in inventory) }\end{array}$ & 0,807 & - & \\
\hline & \multirow{2}{*}{$\begin{array}{l}\text { Economic } \\
\left(\rho_{\mathrm{n}}=0,821\right. \\
\text { V.E }=0,702)\end{array}$} & $\begin{array}{l}\text { Significant improvement in terms of resources } \\
\text { management efficiency }\end{array}$ & 0,961 & 4,194 & $<0,001$ \\
\hline & & $\begin{array}{l}\text { Significant improvement in terms of sales and market } \\
\text { share }\end{array}$ & 0,694 & - & \\
\hline & \multirow{2}{*}{$\begin{array}{l}\text { Social } \\
\quad\left(\rho_{\eta}=0,758\right. \\
V . E=0,611)\end{array}$} & Significant improvement in product image & 0,766 & 5,850 & $<0,001$ \\
\hline & & $\begin{array}{l}\text { Significant improvement in its image in the eyes of its } \\
\text { customer }\end{array}$ & 0,797 & - & \\
\hline \multirow{6}{*}{ 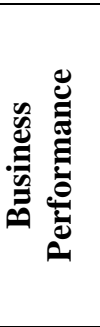 } & \multirow{3}{*}{$\begin{array}{l}\text { Qualitative } \\
\text { Performance } \\
\left(\rho_{\eta}=0,824\right. \\
\text { V.E }=0,613) \\
\end{array}$} & The quality of goods / service has increased. & 0,904 & - & \\
\hline & & Skill of new product development has increased. & 0,707 & 7,745 & $<0,001$ \\
\hline & & Internal / external customer satisfaction has increased. & 0,723 & 7,916 & $<0,001$ \\
\hline & \multirow{3}{*}{$\begin{array}{l}\text { Quantitative } \\
\text { Performance } \\
\left(\rho_{\eta}=0,813\right. \\
\text { V.E }=0,593)\end{array}$} & Sales have increased & 0,815 & - & \\
\hline & & Market share has increased & 0,764 & 7,700 & $<0,001$ \\
\hline & & The return of the investment was occurred as planned. & 0,729 & 7,449 & $<0,001$ \\
\hline \multirow{6}{*}{ 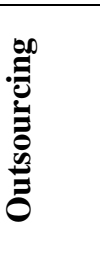 } & \multirow{6}{*}{$\begin{array}{l}\left(\rho_{\eta}=0,878\right. \\
\text { V.E }=0,552\end{array}$} & Logistics & 0,534 & - & \\
\hline & & Communication & 0,678 & 7,340 & $<0,001$ \\
\hline & & Staffing & 0,927 & 6,153 & $<0,001$ \\
\hline & & Training Activities & 0,721 & 4,984 & $<0,001$ \\
\hline & & Management Activities & 0,780 & 5,773 & $<0,001$ \\
\hline & & Administrative Activities & 0,764 & 6,308 & $<0,001$ \\
\hline
\end{tabular}

In table 3, the values of all scales and their standardized loads, $t$ values and significance levels corresponding to $t$ values are given. Additionally, the structural reliability $(\rho \eta)^{4}$ and variance explained $(\mathrm{VE})^{5}$ values of each scale are given in parentheses. The reliability of the structure should be greater than 0.70 whereas the variance explained should be above the value of 0.50 (Fornell and Larcker, 1981: 45-46; Hair et al., 1998: 612). When the tables are examined, it can be seen that the reliability values of each scale are greater than

${ }^{4} \rho \eta$ : Structure reliability $=\left(\sum \text { standardized reg. weight }\right)^{2} /\left(\sum \text { standardize reg. }\right)^{2}+\sum$ measurement errors

${ }^{5}$ VE: Explained Variance $=\sum$ (standardize reg. weight. $\left.{ }^{2}\right) / \sum\left(\right.$ standardize reg. weight. $\left.{ }^{2}\right)+\sum$ measurement errors. These formulas are used. 
0.70 and the variances explained are also higher than 0,50 . The $t$ values corresponding to the standardized loads of the items representing each scale were statistically significant. In this context, same results identified in the EFA were also identified in the CFA within each of the three scales.

Table 4. Compliance Measures for Confirmatory Factor Analysis

\begin{tabular}{|c|c|c|c|c|c|}
\hline $\begin{array}{c}\text { Compliance } \\
\text { Analysis }\end{array}$ & $\begin{array}{c}\text { Good } \\
\text { Compliance }\end{array}$ & $\begin{array}{c}\text { Acceptable } \\
\text { Compliance }\end{array}$ & $\begin{array}{c}\text { Sustainable Supply } \\
\text { Chain Performance }\end{array}$ & $\begin{array}{c}\text { Outsourcing } \\
\text { Activities }\end{array}$ & $\begin{array}{c}\text { Business } \\
\text { Performance }\end{array}$ \\
\hline $\mathrm{x}^{2}$ & & & 41,637 & 3,490 & 15,756 \\
\hline $\mathrm{df}$ & & & 24 & 4 & 8 \\
\hline $\mathrm{x}^{2} / \mathrm{df}$ & $0 \leq \mathrm{x}^{2} / \mathrm{df} \leq 3$ & 1,735 & 0,873 & 1,969 \\
\hline GFI & $0,95 \leq \mathrm{GFI} \leq 1$ & $0,90 \leq \mathrm{GFI} \leq 0,94$ & 0,925 & 0,990 & 0,958 \\
\hline AGFI & $0,90 \leq \mathrm{AGFI} \leq 1$ & $0,85 \leq \mathrm{AGFI} \leq 0,89$ & 0,860 & 0,947 & 0,891 \\
\hline NFI & $0,95 \leq \mathrm{NFI} \leq 1$ & $0,90 \leq \mathrm{NFI} \leq 0,94$ & 0,917 & 0,992 & 0,948 \\
\hline RFI & $0,90 \leq \mathrm{RFI} \leq 1$ & $0,85 \leq \mathrm{RFI} \leq 0,89$ & 0,876 & 0,968 & 0,902 \\
\hline IFI & $0,90 \leq \mathrm{IFI} \leq 1$ & $0,85 \leq \mathrm{IFI} \leq 0,89$ & 0,963 & 1 & 0,974 \\
\hline CFI & $0,97 \leq \mathrm{CFI} \leq 1$ & $0,95 \leq \mathrm{CFI} \leq 96$ & 0,962 & 1 & 0,973 \\
\hline RMSEA & $\begin{array}{c}0 \leq \mathrm{RMSEA} \\
\leq 0,05\end{array}$ & $\begin{array}{c}0,05 \leq \mathrm{RMSEA} \\
\leq 0,10\end{array}$ & 0,079 & 0,000 & 0,090 \\
\hline
\end{tabular}

$\mathrm{x}^{2}$ :Chi-square, df:degrees of freedom, GFI=Goodness Of Fit Index, AGFI: Adjusted Goodness of Fit Index, NFI: Normed Fit Index, RFI: Relative Fit Index, IFI:Incremental Fit Index, CFI: Comperative Fit Index, RMSEA: RootMeanSquareError of Approximation, Anderson and Gerbing 1984, Cole 1987, Marsh and Hocevar 1988, Schermelleh-Engel et al. 2003, Haşlaman 2005, Çakır and Çakır 2007, Tezcan 2008, Eminoğlu and Nartgün 2009.

When Table 4 is examined, the variables of the structural model and the results of the compliance measures related to these variables show that the dimensions are consistent with the data and they are also statistically valid and meaningful.

\subsubsection{Results of Structural Equation Analysis}

After verification of the main variables of the research model, in the testing process of the structural model, in other words the hypotheses, SEM was carried out. Before evaluating the relations on conceptual model, necessity is given in determination of the model's significance and validity statistically. Compliance measurements of CFA are given in Table 5 below.

Table 5. Structural Model Compliance Analysis

\begin{tabular}{|c|c|c|c|}
\hline $\begin{array}{c}\text { Compliance } \\
\text { Analysis }\end{array}$ & Good Compliance & Acceptable Compliance & Model Proposed \\
\hline $\mathrm{x}^{2}$ & & & 59,145 \\
\hline $\mathrm{df}$ & & & 37 \\
\hline $\mathrm{x}^{2} / \mathrm{df}$ & $0 \leq \mathrm{x}^{2} / \mathrm{df} \leq 3$ & $\leq 5$ & 1,599 \\
\hline $\mathrm{GFI}$ & $0,95 \leq \mathrm{GFI} \leq 1$ & $0,90 \leq \mathrm{GFI} \leq 0,94$ & 0,922 \\
\hline $\mathrm{AGFI}$ & $0,90 \leq \mathrm{AGFI} \leq 1$ & $0,85 \leq \mathrm{AGFI} \leq 0,89$ & 0,861 \\
\hline $\mathrm{NFI}$ & $0,95 \leq \mathrm{NFI} \leq 1$ & $0,90 \leq \mathrm{NFI} \leq 0,94$ & 0,906 \\
\hline RFI & $0,90 \leq \mathrm{RFI} \leq 1$ & $0,85 \leq \mathrm{RFI} \leq 0,89$ & 0,860 \\
\hline IFI & $0,90 \leq \mathrm{IFI} \leq 1$ & $0,85 \leq \mathrm{IFI} \leq 0,89$ & 0,961 \\
\hline CFI & $0,97 \leq \mathrm{CFI} \leq 1$ & $0,95 \leq \mathrm{CFI} \leq 96$ & 0,071 \\
\hline RMSEA & $0 \leq \mathrm{RMSEA} \leq 0,05$ & $0,05 \leq \mathrm{RMSEA} \leq 0,10$ & \\
\hline
\end{tabular}

$\mathrm{x}^{2}$ :Chi-square, df:degrees of freedom, GFI=Goodness Of Fit Index, AGFI: Adjusted Goodness of Fit Index, NFI: Normed Fit Index, RFI: Relative Fit Index, IFI:Incremental Fit Index, CFI: Comperative Fit Index, RMSEA: RootMeanSquareError of Approximation, 
Anderson and Gerbing 1984, Cole 1987, Marsh and Hocevar 1988, Schermelleh-Engel et al. 2003, Haşlaman 2005, Çakır and Çakır 2007, Tezcan 2008, Eminoğlu and Nartgün 2009.

In table 5, the results of the compliance values of the structural model show that the developed conceptual model is consistent with the data and that the model is statistically valid and significant. In this context, to be able to evaluate the hypotheses given in the research model, proposed model has met the validity requirements.

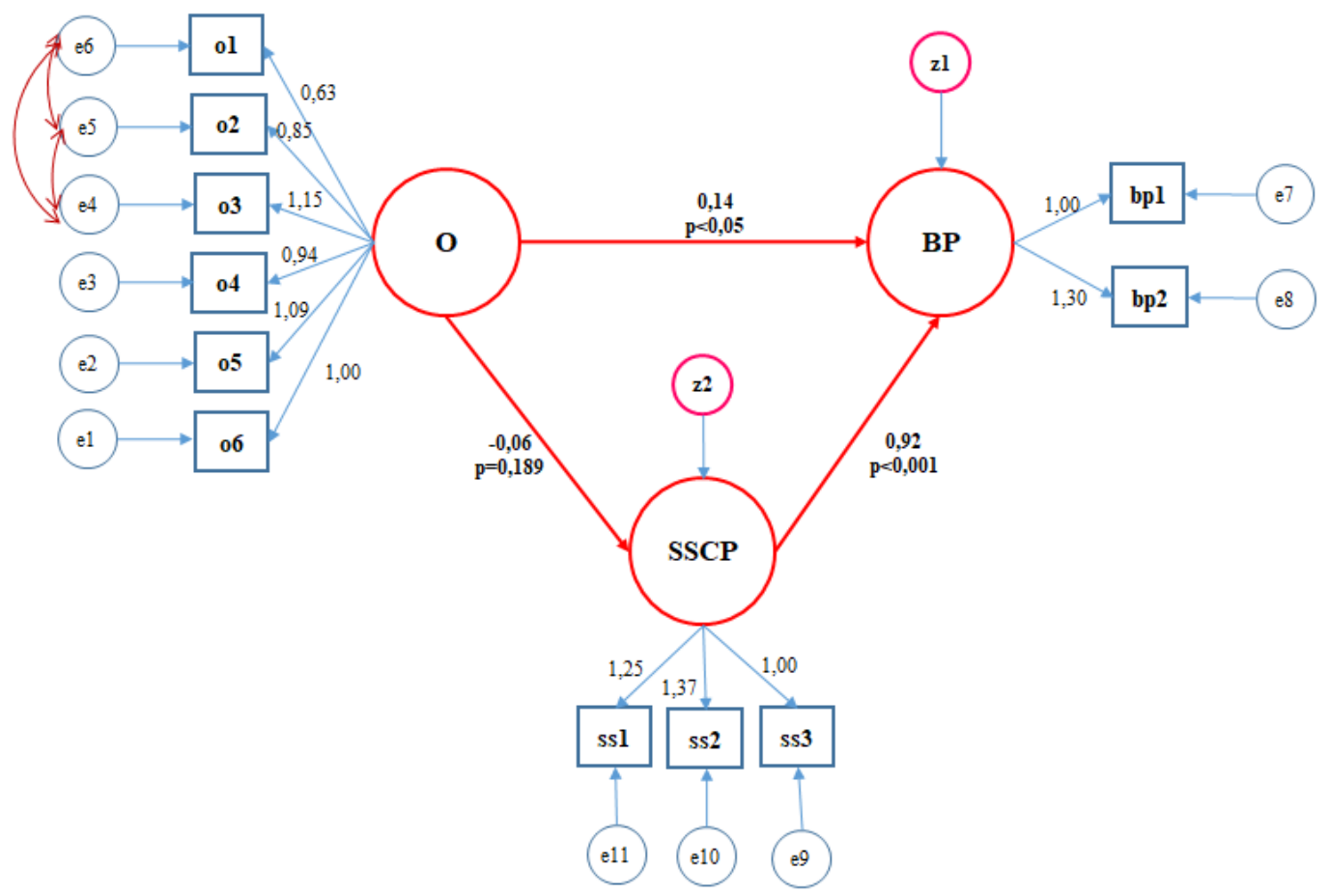

Figure 2. Results of SEM Analysis on Conceptual Model

The information in Figure 2 can be summarized as in Tables 6 and 7.

Table 6. Results of SEM Analysis on Conceptual Model

\begin{tabular}{|l|l|c|c|c|}
\hline \multicolumn{1}{|c|}{ Scale } & \multicolumn{1}{|c|}{ Item } & Standard Estimate & Standard Error & \multicolumn{1}{c|}{$\boldsymbol{t}^{*}$} \\
\hline \multirow{3}{*}{$\begin{array}{l}\text { Sustainable Supply } \\
\text { Chain Performance }\end{array}$} & Operations & 1,250 & 0,246 & 5,092 \\
\cline { 2 - 5 } & Economic & 1,373 & 0,259 & 5,299 \\
\cline { 2 - 5 } & Social & 1,000 & - & - \\
\hline \multirow{4}{*}{ Business Performance } & Qualitative Performance & 1,000 & - & - \\
\cline { 2 - 5 } & $\begin{array}{l}\text { Quantitative } \\
\text { Outsourcing }\end{array}$ & 1,300 & 0,240 & 5,423 \\
\hline & Performance & 0,630 & 0,101 & 6,246 \\
\cline { 2 - 5 } & Cogistics & 0,630 & 0,101 & 6,246 \\
\cline { 2 - 5 } & Staffing & 1,147 & 0,106 & 8,106 \\
\cline { 2 - 5 } & Training Activities & 0,940 & 0,116 & 9,029 \\
\cline { 2 - 5 } & Management Activities & 1,085 & 0,120 & - \\
\cline { 2 - 5 } & Administrative Activities & 1,000 & - & \\
\hline
\end{tabular}

$*: \mathrm{p}<, 001$ for all $\mathrm{t}$ values 
Table 7. Hypothesis Test Results

\begin{tabular}{|l|c|c|c|c|c|}
\hline \multicolumn{1}{|c|}{ Hypothesis } & $\begin{array}{c}\text { Std. } \\
\text { Estimate }\end{array}$ & $\begin{array}{c}\text { Std. } \\
\text { Error }\end{array}$ & $\mathbf{t}$ & $\mathbf{p}$ & Result \\
\hline $\begin{array}{l}\text { There is a relationship between outsourcing and } \\
\text { sustainable supply chain performance. }\end{array}$ & $-0,061$ & 0,047 & $-1,313$ & 0,189 & Rejected \\
\hline $\begin{array}{l}\text { There is a relationship between sustainable supply } \\
\text { chain performance and business performance. }\end{array}$ & 0,919 & 0,223 & 4,113 & $<0,001$ & Accepted \\
\hline $\begin{array}{l}\text { There is a relationship between outsourcing and } \\
\text { business performance. }\end{array}$ & 0,137 & 0,044 & 3,133 & $<0,05$ & Accepted \\
\hline
\end{tabular}

When Figure 2, Tables 6 and 7 are evaluated together, the correlation coefficient between outsourcing and sustainable supply chain performance is $-0,061$ and $p$ value is 0,189 . These results do not support the hypothesis 1 which says "There is a positive relationship between outsourcing and sustainable supply chain performance".

The correlation coefficient between sustainable supply chain performance and business performance is 0,919 and $\mathrm{p}$ value is $<0,001$. According to these results, the hypothesis 2 as "There is a positive relationship between sustainable supply chain performance and business performance" is accepted.

The correlation coefficient between outsourcing variable and business performance is 0,137 and $p$ value of significance level is $<0,05$. Therefore, the hypothesis 3 as "There is a positive relationship between outsourcing and business performance" is also accepted.

\section{CONCLUSION AND DISCUSSION}

This study was conducted to determine the relationship between outsourcing, sustainable supply chain performance and business performance on 120 companies registered in the Konya Chamber of Commerce operating under industry in Konya.

First of all, in order to determine the accuracy of the hypotheses proposed, a conceptual model has been developed. The reliability of the scales used in this conceptual model was tested and exploratory factor analysis and confirmatory factor analysis were also performed.

As the result of the analysis, relationship was not identified between outsourcing and sustainable supply chain performance. On the other hand, there is relationship between sustainable supply chain performance and outsourcing as well as sustainable supply chain performance and business performance.

Supply Chain Management is a business function that aims to manage and coordinate activities on the supply chain that link suppliers, internal departments, distributors, customers and information systems. It is a management system that covers the entire raw materials 
supply, production, storage, marketing, order management, distribution and customer delivery activities a product from the process of its source to the end user. It is necessary for managers to perform their supply chain activities in the best way and to restructure the supply chain in order to be sustainable. Using outsourcing, managers can increase their revenues because of the competitive advantage, and they can also get more shares in the market due to their service quality and this can increase their revenue and turnover as a whole.

There are some limitations in this study. The most important of these are time and financial resource constraints. This study has been carried out on the food enterprises registered in Konya Chamber of Commerce and operating in Konya. The results cannot be generalized for the whole country or province because of the sample size. However, further studies can be conducted on different samples and in different sectors. Moreover, comparative studies on different sectors can also contribute well to the literature. 


\section{REFERENCES}

Alpay, G., Bodur, M., Yılmaz, C., Çetinkaya. S. \& Arıkan, L. (2008). Performance Implications of Institutıonalization Process in Family-Owned Businesses: Evidence From an Emering Economy. Journal of Word Business, 43, 435-448.

Altuntaş, C. \& Türker, D. (2012). Sürdürülebilir Tedarik Zincirleri: Sürdürülebilirlik Raporlarının İçerik Analizi. Dokuz Eylül Üniversitesi Sosyal Bilimler Enstitüsü Dergisi, 14(3), 39-64.

Anderson, J. C. \& Gerbing, D. W. (1984). The effect of sampling error on convergence, improper solutions, and goodness-offit indices for maximum likelihood confirmatory factor analysis. Psychometrika, 49, 155-173.

Aydın, N. (2016). Dış Kaynak Kullanım Nedenleri ve Uygulamalar. ABMYO Dergisi, 41, 61-79.

Ayyıldız, H., Cengiz, E. \& Ustasüleyman, T. (2006). Üretim ve Pazarlama Bölüm Çalışanları Arası Davranışsal Değişkenlerin Firma Performansı Üzerine Etkisine İlişkin Yapısal Bir Model Önerisi. Muğla Üniversitesi Sosyal Bilimler Enstitüsü Dergisi (İLKE), Sayı 17.

Bastas, A. \& Liyanage, K. (2018). Sustainable supply chain quality management: A systematic review, Journal of Cleaner Production, 181, 726-744.

Beske-Janssen, P., Johnson, M.P \& Schaltegger, S. (2015). 20 years of performance measurement in sustainable supply chain management-what has been achieved?. Supply Chain Management: An International Journal, 20(6), 664-680.

Beske-Janssen, P., Johnson, M.P. \& Schaltegger, S. (2015). 20 years of performance measurement in sustainable supply chain management - what has been achieved?. Supply Chain Management: An International Journal, 20(6), 664-680.

Carte, C.R. \& Easton, P.L. (2011). Sustainable supply chain management: evolution and future directions, International Journal of Physical Distribution \& Logistics Management, 41(1), 46-62.

Cole, D. A. (1987). Utility of confirmatory factor analysis in test validation research. Journal of Consulting and Clinical Psychology, 55, 1019-1031.

Çakır, V. \& Çakır, V. (2007). Televizyon Reklamlarının Algılanan Değeri ve Reklam Tutumu İlişkisi: Bir Yapısal Eşitlik Modeli. İstanbul Üniversitesi İletişim Fakültesi Dergisi, 30, 37-59.

Eminoğlu, E. \& Nartgün, Z. (2009). Üniversite Öğrencilerinin Akademik Sahtekarlık Eğilimlerinin Ölçülmesine Yönelik Bir Ölçek Geliştirme Çalışması. Uluslararası İnsan Bilimleri Dergisi, 6(1), s.215-240

Erdirençelebi, M. (2012). Aile İşletmelerinde Kurumsallaşmanın Gerçekleşmesi İle Sürdürülebilirliğin Sağlanmasında Kuşaklar Arası Farklılıklar. Selçuk Üniversitesi Sosyal Bilimler Enstitüsü, Doktora Tezi, Konya.

Fill, C. \& Visser, E. (2000). The Outsourcing Dilemma: A Composite Approach to the Make or Buy Decision”, Management Decision. 38(1), s.43-50.

Fornell, C. \& Larcker, D.F. (1981). Evaluating Structural Equation Models with Unobservable Variables and Measurement Error. J. Mark. Res., 18(1), 39-50.

Giustiniano, L. \& Clarioni, G. (2013). The Impact of Outsourcing on Business Performance: An Empirical Analysis. Journal of Modern Accounting and Auditing, 9(2), 153-168.

Gomez-Luciano, C.A., Dominguez, F.R.R., Gonzalez-Andres, F. \&Meneses, B.U.L.D. (2018),

Gupta, S. \& Palsule-Desai, O.D. (2011). Sustainable supply chain management: Review and research opportunities, IIMB Management Review, 23, 234-245.

Güleş, H.K., Paksoy, T, Bülbül, H. \& Özceylan, E. (2012). Tedarik Zinciri Yönetimi: Stratejik Planlama, Modelleme ve Optimizasyon, Gazi Kitabevi: Ankara.

Hair JF, Andreson RE, Tahtam RL \& Black CW (1998). Multivariate Data Analysis. Fifth Edition Prentice-Hall International Inc. New Jersey.

Haşlaman, T. (2005). Programlama Dersi İle İlgili Özdüzenleyici Öğrenme Stratejileri İle Başarı Arasındaki İlişkilerin İncelenmesi: Bir Yapısal Eşitlik Modeli. Yüksek Lisans Tezi, Hacettepe Üniversitesi Fen Bilimleri Enstitüsü, Ankara. 
Hila, C.M. \& Dumitraşcu, O. (2014). Outsourcing Within A Supply Chain Management Framework, Proceedings of the 8th International Management Conference "Management Challenges for Sustainable Development". November 6th-7th, 2014, Bucharest, Romania, 328-336.

Hong, J., Zhang, Y. \&Ding, M. (2018). Sustainable supply chain management practices, supply chain dynamic capabilities, and enterprise performance. Journal of Cleaner Production, 172, 3508-3519.

Karahan, A. (2009). Dış Kaynak Kullanımının Verimlilik Üzerine Etkisi Hastane Yöneticileri Üzerine Bir Araştırma. Balıkesir Üniversitesi, Sosyal Bilimler Enstitüsü Dergisi, 12(21), 185-199.

Lacity, M.C., Willcocks L.P. \& Feeny, D. F. (1995). IT Outsourcing: Maximize Flexibility and Control. Harvard Business Review, May-June, 84-93.

Linton, J.D., Klassen, R. \& Jayaraman, V. (2007). Sustainable supply chains: An introduction. Journal of Operations Management, 25, 1075 -1082.

Mariados, B.J., Hong, J., Zhang, Y. \& Ding, M. (2016). Influences of Firm Orientations on Sustainable Supply Chain Management . Journal of Business Research, 69, 3406-3414.

Marsh, H. W. \& Hocevar, D. (1988). A New, More Powerful Approach to Multitrait-Multimethod Analyses: Application Of Second-Order Confirmatory Factor Analysis. Journal of Applied Psychology, 73 (1), 107117.

May, A.S. (1998). Business Process Outsourcing: A New Test Of Management Competence. Career Developement International, 3(4), 136-141.

Mieghem, J.A. (1999). Coordinating investment, production and subcontracting. Managament Science, 45 (7), 954-971.

Momme, J. (2002). Framework for outsourcing manufacturing: Strategic and operational implications. Computers in Industry, 49, 59-75.

Nakip, M. (2013). Pazarlamada Araştırma Teknikleri SPSS Uygulamalı, 3. Baskı, Seçkin Yayıncılık.

Öz, M. (2011). Lojistik Faaliyetlerde Dış Kaynak Kullanımı ve Üçüncü Parti Lojistik İşletmelerinin Firmaların Pazarlama Tabanlı Temel Yeteneklerini Oluşturmada ve Müşteri Değerini Arttırmadaki Rolü. Selçuk Üniversitesi Sosyal Bilimler Enstitüsü, Yayınlanmamış Doktora Tezi, Konya.

Saeed, M.A. \& Kersten, W. (2017). Supply chain sustainability performance indicators-a content analysis based on published standards and guidelines. Logistics Research, 10(12), 1-19.

Saeed, M.A. \& Kersten, W. (20177). Supply chain sustainability performance indicators - a content analysis based on published standards and guidelines. Logistics Research, 10 (12), s. 1-19.

Sarifuzzaman, M. (2012). Impact of Outsourcing on Company Performance: Study on a Local Public Limited Company in Bangladesh. Dhaka, Bangladesh: Institute of Governance Studies, BRAC University.

Schermelleh-Engel, K., Moosbrugger, H. \& Müller, H. (2003). Evaluating the fit of structural equation models: Tests of significance and descriptive goodness-of-fit measures. Methods of Psychological Research Online, 8(2), 23-74.

Seuring, S., \& Müller, M. (2008). From a literature review to a conceptual framework for sustainable supply chain management. Journal of Cleaner Production, 16 (15), 1699-1710.

Sustainable supply chain management: Contributions of supplies markets, Journal of Cleaner Production, 184, 311-320.

Tezcan, C. (2008). Yapısal Eşitlik Modelleri. Yüksek Lisans Tezi, Hacettepe Üniversitesi Fen Bilimleri Enstitüsü, Ankara.

Yazıcıŏ̆lu, Y. \& Erdoğan, S. (2004). Spss Uygulamalı Bilimsel Araştırma Yöntemleri, Ankara: Detay Yayıncılık.

Zailani, S., Jeyaraman, K., Vengadasan, G. \& Premkumar, R. (2012). Sustainable supply chain management (SSCM) in Malaysia: A survey. Int. J. Production Economics, 140, 330-340.

Zhang, M., Tse, Y.K., , Doherty, B., Li, S. \& Akhtar, P. (2018),. Sustainable supply chain management: Confirmation of a higher-order model. Resources, Conservation and Recycling, 128, 206-221. 